\title{
Subglacial hydrological connectivity within the Byrd Glacier catchment, East Antarctica
}

\author{
A.P. WRIGHT, ${ }^{1}$ D.A. YOUNG, ${ }^{2}$ J.L. BAMBER, ${ }^{1}$ J.A. DOWDESWELL, ${ }^{3}$ A.J. PAYNE, ${ }^{1}$ \\ D.D. BLANKENSHIP, ${ }^{2}$ M.J. SIEGERT ${ }^{1}$
}

\author{
${ }^{1}$ Bristol Glaciology Centre, School of Geographical Sciences, University of Bristol, Bristol, UK \\ E-mail: m.j.siegert@bristol.ac.uk \\ ${ }^{2}$ Institute for Geophysics, Jackson School of Geosciences, University of Texas at Austin, Austin, TX, USA \\ ${ }^{3}$ Scott Polar Research Institute, University of Cambridge, Cambridge, UK
}

\begin{abstract}
Ice, Cloud and land Elevation Satellite (ICESat) repeat-track laser altimetry has identified 17 sites within the Byrd Glacier catchment, East Antarctica, where rapid ice-surface height changes have occurred, which have been interpreted as evidence for 'active' subglacial lakes. Here we present evidence from a new radio-echo sounding (RES) survey at 11 of these locations to understand the bed conditions associated with the proposed hydrological activity. At none of the sites examined did we find evidence in support of substantial pooled basal water. In the majority of cases, along-track RES bed reflection amplitudes either side of the locations of surface height change are indistinguishable from those within the features. These results indicate that, in most cases, hypothesized 'active' lakes are not discrete radar targets and are therefore much smaller than the areas of surface height change. In addition, we have identified three new relatively large subglacial lakes upstream of the region where most 'active' subglacial lakes are found, in an area where the hydraulic gradient is significantly lower. Our results suggest that substantial and long-lasting basal water storage in the Byrd Glacier catchment occurs only under low hydraulic gradients, while coast-proximal sites of hydraulic activity likely involve small or temporary accumulations of basal water.
\end{abstract}

KEYWORDS: Antarctic glaciology, radio-echo sounding, satellite altimetry, subglacial lakes

\section{INTRODUCTION}

Water storage beneath the East Antarctic ice sheet has been known since subglacial lakes were first reported by radioecho sounding (RES) studies undertaken during the late 1960s and early 1970s (Robin and others, 1970). In contrast to common ice-bed interface reflections, a reflection from the surface of a deep-water subglacial lake can be distinguished by its bright, smooth, hydraulically flat and uniform character (Oswald and Robin, 1973; Siegert and others, 2005; Carter and others, 2007). Using RES, it is rarely possible to make reliable estimates of the absolute magnitude of basal reflective power due to the highly variable degree of englacial radio-wave absorption (Matsuoka, 2011). The relative magnitude of a bed reflection (i.e. the brightness of a potential subglacial lake relative to its immediate surroundings) is, however, a much more reliable indicator of the presence of water. One exception is where the water column is < 10 m (Gorman and Siegert, 1999). Very shallow lakes may therefore be difficult to detect by RES, especially where they are located in regions of low bed relief and/or where the bed is composed of water-saturated sediments, which themselves are likely to produce bright and smooth reflections (e.g. Christianson and others, 2012; Horgan and others, 2012).

The majority of subglacial lakes detected previously by RES are located $<200 \mathrm{~km}$ from an ice divide. In these areas ice-flow velocities and hydrological potential gradients are low (Wright and Siegert, 2011). Over 20 lakes have been identified by either RES or satellite imagery in the onset regions of enhanced ice flow, however, where both ice-surface and hydraulic gradients are higher (Siegert and Bamber, 2000; Bell and others, 2007). These enhanced gradients may act to drive basal water both into and out of subglacial lakes, making them less likely to be hydrologically isolated than those in the ice-sheet interior and, therefore, more likely to play a role in channelling significant fluxes of water to the beds of ice streams.

Discrete zones of rapid ice-surface elevation change (of a few metres and over a time frame of a few months) have been interpreted as evidence of 'active' subglacial lakes. In a (currently) unique observation, rapid decreases in ice-surface elevation at two sites $\sim 200 \mathrm{~km}$ upstream of the Byrd Glacier grounding line, inferred to be caused by the transfer of $>1 \mathrm{~km}^{3}$ of water, were found to coincide with a $10 \%$ increase in ice-flow velocity of the glacier trunk (Stearns and others, 2008). In their inventory of ice-surface height change features, Smith and others (2009) identified a further 15 sites of rapid ice-elevation change within the lower Byrd Glacier catchment. These observations potentially make the bed of Byrd Glacier the most hydrologically active location in East Antarctica (Smith and others, 2009).

As yet, no subglacial lakes identified previously by RES are coincident with Ice, Cloud and land Elevation Satellite (ICESat)-derived locations of rapid ice-surface height change (Wright and Siegert, 2011). Recent RES surveys of two subglacial lakes proposed by Smith and others (2009), one in the Nimrod Glacier catchment and one $\left(\right.$ Byrd $\left._{\mathrm{s12}}\right)$ in the Byrd Glacier catchment, failed to detect any of the RES features normally used to identify subglacial lakes (Welch and others, 2009). Both of these sites were reported by Smith 


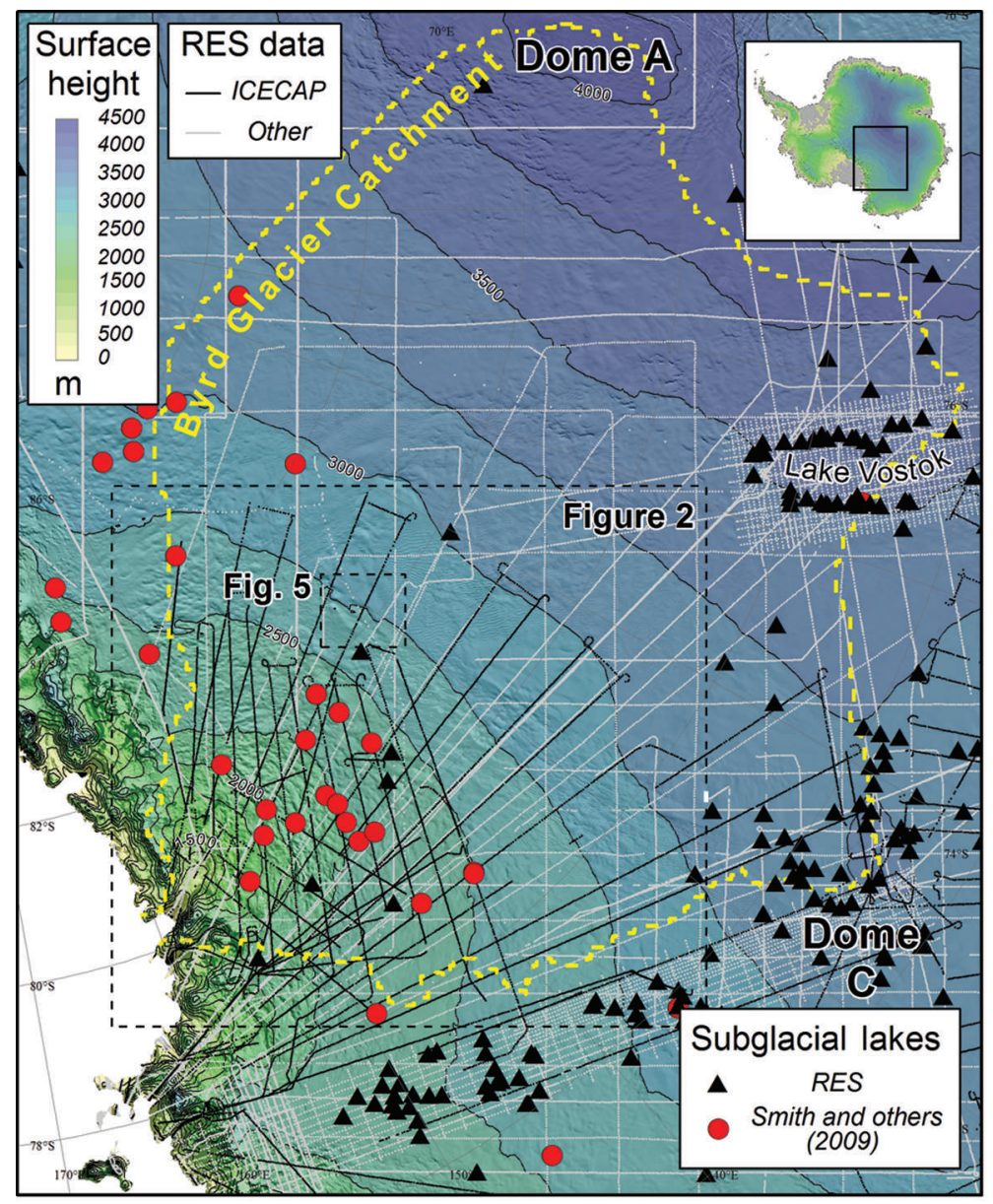

Fig. 1. Topographic map of the Byrd Glacier catchment with ice-surface height shown on a colour scale and with contours at $250 \mathrm{~m}$ spacing superimposed on the MODIS Mosaic of Antarctica (Haran and others, 2006). Locations of the geophysical data used to construct the bed topography are shown in black (ICECAP) and light grey (other surveys). Subglacial lakes identified in previous RES work are indicated with black triangles, and ice-surface height change anomalies identified on repeat ICESat tracks are shown as red circles.

and others (2009) to have been filling with water at least until early 2008, but were found to have the RES characteristics expected of a 'drained lake' when crossed by the International Trans-Antarctic Scientific Expedition (ITASE) traverse during the 2007/08 field season (Welch and others, 2009). A water-rich (but non-lake) ice/bed interface was also interpreted from a RES survey at the site of recent ice-surface lowering in the Recovery Glacier catchment by Langley and others (2011), while two sites of ice-surface elevation change Totten $_{2}$ in the Aurora Basin and L1 in the Adventure Trench) have been shown by RES to correspond to 'bright but fuzzy' subglacial reflections (cf. Carter and others, 2007), which are not obviously interpretable as deep-water lake reflections (Wright and others, 2012). In West Antarctica, Siegert and others (2014) measured an 'active' subglacial lake in the upper Institute Ice Stream with a targeted RES survey, yet found little evidence for significant stored water. As a result of these investigations, a degree of uncertainty currently exists about 'active' subglacial lakes identified from satellite-derived ice-surface height changes. In this paper, we use a new extensive airborne RES dataset, collected during a systematic survey of the Byrd Glacier catchment, to investigate bed conditions at and around the locations of ICESat ice-surface elevation changes in order to improve our comprehension of the subglacial hydrological system in East Antarctica.

\section{GEOPHYSICAL DATA}

During three seasons (2008/09, 2009/10 and 2010/11 austral summers) the international ICECAP programme (International Collaborative Exploration of the Cryosphere through Airborne Profiling) acquired a total of $45000 \mathrm{~km}$ of alongtrack geophysical data from the southern Wilkes Subglacial Basin (WSB), including the trunk and lower catchment of Byrd Glacier and extending as far inland as the ice divide at Dome C (Fig. 1). The survey design was a combination of a radial array centred at McMurdo station and a near-isometric grid composed of sections of ICESat tracks over the convergence region of Byrd Glacier. The ICESat tracks were selected partly with the aim of surveying the surface-height change features reported by Smith and others (2009). As a result, 11 of the 17 previously proposed sites of hydrological activity in the lower Byrd catchment were transited directly during the survey (Fig. 1).

The survey utilized the High-Capability Radar Sounder (HiCARS) coherent ice-penetrating RES system (Peters and others, 2005). HiCARS transmits $53-67 \mathrm{MHz}$ frequency chirped pulses of $1 \mu$ s duration, 6400 times per second. Returned RES pulses were compressed using a reference signal from a smooth air/sea-ice reflection obtained near McMurdo station. Samples were digitized at a rate of $50 \mathrm{~Hz}$, and initial along-track coherent integration was performed for every 16 samples. Coherent integration of pulses 
received within an aperture of $\sim 66 \mathrm{~m}$ was later used for unfocused synthetic aperture radar post-processing of the data in order to improve the along-track resolution, resulting in the product used for this study. Ice thickness was determined from the time between surface and bed reflections using a speed of electromagnetic wave propagation in ice of $169 \mathrm{~m} \mathrm{\mu s}^{-1}$ (Dowdeswell and Evans, 2004). No correction was applied for the increased radio-wave velocity in firn. The appropriate firn correction is likely to be on the order of a $10 \mathrm{~m}$ reduction in ice thickness and this may vary by $\sim \pm 2 \mathrm{~m}$ with changes in the firn density across the study area. This variation is small relative to the total error in ice thickness measurements, which crossover analyses indicate to be around $\pm 1 \%$ of the measured ice thicknesses. Range distortions in the resulting dataset limit the minimum feature size that can be distinguished at the bed to $\sim 400 \mathrm{~m}$. Subglacial lakes smaller than this may not, therefore, be detectable in our radargrams.

\section{BED TOPOGRAPHY}

ICECAP RES measurements of ice thickness were combined with previous ice thickness data from the Wilkes Corridor (Studinger and others, 2004) and Vostok Subglacial Lake (Studinger and others, 2003) surveys undertaken by the US Support Office for Aerogeophysical Research (SOAR) during the early 2000s, the Scott Polar Research Instiute (SPRI)-US National Science Foundation (NSF)-Technical University of Denmark (TUD) dataset collected in the 1970s, as well as all the US and Russian seismic over-snow traverse data included in the BEDMAP compilation (Lythe and others, 2001). The combined ice thickness dataset was then interpolated using a natural neighbour algorithm (Sibson, 1981) to a grid spacing of $5 \mathrm{~km}$. Ice-sheet bed elevations were calculated by subtracting the gridded ice thickness from the ice-surface digital elevation model (DEM) of Bamber and others (2009) (Fig. 2). This DEM has a calculated error of $<2 \mathrm{~m}$ over the inland part of the Byrd catchment (Griggs and Bamber, 2009) due to the high spatial density and high vertical precision of the ICESat measurements in this area.

The deepest point of the southern WSB measured by the ICECAP RES system is near $80^{\circ} \mathrm{S}, 139.5^{\circ} \mathrm{E}$ and is $755 \mathrm{~m}$ below the World Geodetic System 1984 ellipsoid elevation (WGS84) sea level. The WSB shallows towards the south until a highland area is met at $\sim 83^{\circ} \mathrm{S}$, which separates the Wilkes basin from the more southerly basins. Likewise, the WSB is bounded to the east, and separated from a previously unnamed basin to the south of the Vincennes Subglacial Basin (VSB), by a bed-ridge between 0 and $500 \mathrm{~m}$ a.s.l. This ridge extends northwards for $>600 \mathrm{~km}$ roughly following the $130^{\circ} \mathrm{E}$ meridian as far as Dome C (Fig. 2).

\section{HYDRAULIC FLOW PATHS}

Subglacial hydrological potential is calculated from Bamber and others' (2009) surface DEM and the gridded bed dataset described in Section 3. Subglacial flow paths can be calculated if it is assumed that subglacial water pressure is equal to the ice overburden pressure. Further details of this method are described in Wright and others (2008). The large-scale direction of subglacial water flow is controlled by ice-sheet surface slope. The subglacial hydrological catchment of Byrd Glacier therefore closely mirrors the
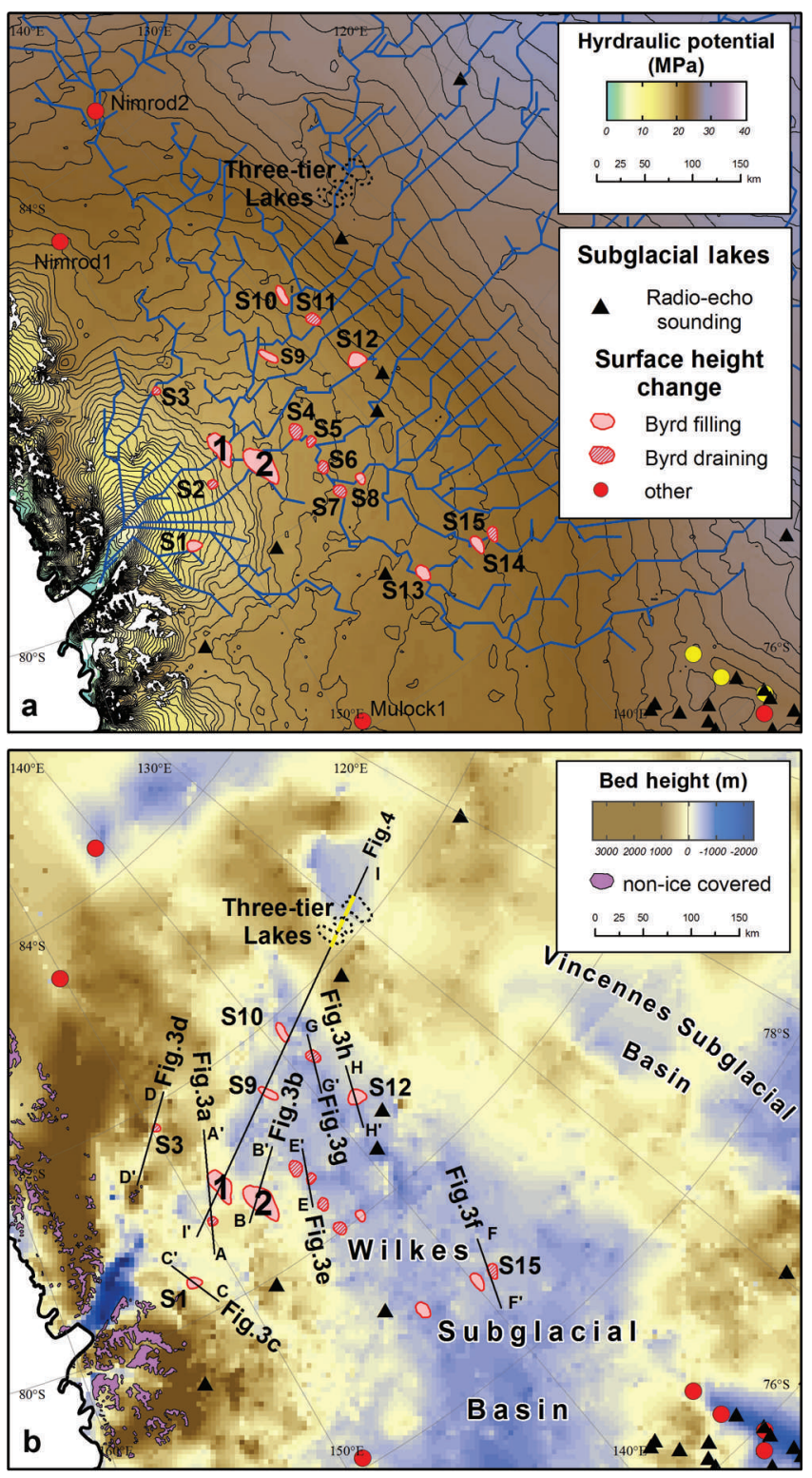

Fig. 2. (a) Hydraulic potential map of the Byrd Glacier catchment with contours at $5 \mathrm{MPa}$ intervals. Predicted subglacial flow paths are shown in blue. (b) Colour-rendered DEM of the bed topography showing the locations of the radar transects in Figures $3 \mathrm{a}-\mathrm{h}$ and 4. In both panels subglacial lakes known from previous RES surveys are shown as black triangles while the three-tier lakes are shown in dashed black outline. Ice-surface height change features within the Byrd subglacial catchment are shown in outline and are shaded to indicate whether they were rising or falling during the ICESat campaign. Those features within the Byrd catchment are labelled in line with the numbering system of Smith and others (2009).

glacial catchment overlying it, with the outlet to the ocean beneath the trunk of the glacier (Fig. 2a). Bed slope has only around one-tenth of the effect of ice-sheet surface slope on the flow of basal water (Shreve, 1972). Ice-surface gradients in Antarctica are generally low, however (Fig. 1), especially on the high interior plateau, so basal topography can have an important local influence (Wright and others, 2008).

Several of the sites of ICESat-derived surface-height change are linked by basal water flow paths predicted using the new bed topography (Fig. 2). The two largest surfacechange features in the catchment $\left(\right.$ Byrd $_{1}$ and Byrd 2 ) are those that were related by Stearns and others (2008) to a speed-up 
of the glacier trunk. The new topography confirms that Byrd is upstream of Byrd $_{1}$ (Fig. 2a), as expected from their discharge history (Stearns and others, 2008). All the additional sites reported by Smith and others (2009) are much smaller and, with the exceptions of Byrd ${ }_{\mathrm{S} 1}$, Byrd $_{\mathrm{s} 2}$ and Byrd $_{\mathrm{S} 3}$, are all upstream of either Byrd ${ }_{1}$ or Byrd 2 (Fig. 2a). All of these features are located on major subglacial water-flow paths, each with an upstream catchment of at least $5000 \mathrm{~km}^{2}$. From the available ICESat epochs all these sites appear to have been either filling or draining monotonically between 2003 and 2008 (Smith and others, 2009). It is therefore difficult to unequivocally detect hydraulic connectivity between sites from these data. The only potential candidates for basal water transfer during this period are Byrd $\mathrm{S} 11_{11}$, which is thought to have drained $0.027 \mathrm{~km}^{3}$ of water $\sim 60 \mathrm{~km}$ upstream of Byrd ${ }_{\mathrm{S} 9}$, which appeared to gain $0.044 \mathrm{~km}^{3}$ over a similar period, and Byrd ${ }_{\mathrm{S} 15}$, which drained $0.035 \mathrm{~km}^{3}$ and is $<20 \mathrm{~km}$ upstream of Byrd ${ }_{\mathrm{s} 14}$, which gained $0.042 \mathrm{~km}^{3}$ (Smith and others, 2009). Over the ICESat period of observation, $<8 \%$ of the water necessary to cause the observed inflation of the two large downstream lakes $\left(\right.$ Byrd $_{1}$ and $\left.B \operatorname{rrd}_{2}\right)$ can be accounted for by water draining from the upstream sites Byrd $_{\mathrm{S} 4}-$ Byrd $_{\mathrm{S} 15}$ (Smith and others, 2009). Either the sources of this water did not cause detectable ice-surface height changes (e.g. significant input from a distributed subglacial drainage system or perhaps discharges from very large lakes) or lake discharges occurred either temporally or spatially between the ICESat tracks and were therefore not detected. Either way, the pattern of basal water filling and discharge interpreted through ICESat indicates that the subglacial hydrological system in this area is much more complex than would appear from Figure 2a.

Bed topography at scales less than $5 \mathrm{~km}$ almost certainly exerts a significant control on subglacial water flow paths that is not captured in current Antarctic DEMs. Sites also exist, in regions of relatively low surface slope, where the direction of basal water is potentially sensitive to very small changes in ice surface elevation (e.g. Wright and others, 2008). Such sensitivity in calculations of basal water flow direction (which may be real or a consequence of inadequate bed data) is likely to affect the upper regions of the Byrd catchment, but is unlikely to influence the general pattern of water flow routing in the lower catchment.

\section{WATER STORAGE IN THE BYRD GLACIER CATCHMENT}

\subsection{Satellite altimetry-derived surface features in the lower Byrd catchment}

At each of the 11 sites of rapid ICESat surface-height change crossed by ICECAP flights (Fig. 2b), the corresponding RES images show a clearly identifiable bed. Reflectors normally taken to be indicative of a subglacial lake, i.e. both smooth and uniformly brighter than their surroundings, are not apparent in any of the radargrams (Fig. 3a-h).

The sites of the two largest proposed 'active' subglacial lakes $\left(\right.$ Byrd $_{1}$ and Byrd $_{2}$ ) are situated in an area of moderately heavy surface crevassing near the confluence region of several of the main glacier tributaries. Despite moderate amounts of radar scattering, probably due to the presence of these crevasses, the bed is clearly visible in RES at both sites (Figs $3 \mathrm{~b}$ and 4). Although the bed reflections appear bright in places, particularly just upstream of the location of Byrd ${ }_{1}$ in Figure 4, the areas covered by the proposed 'active' lakes are characterized by significant subglacial topography with vertical scales of several hundreds of metres over horizontal scales of $1-2 \mathrm{~km}$.

Nine smaller 'active subglacial lake' sites were also transited by ICECAP flights, seven of which followed the ICESat tracks on which rapid surface height changes were first detected. Byrd $\mathrm{S}_{\mathrm{S} 1}$, Byrd $_{\mathrm{S} 2}$ and Byrd $\mathrm{S}_{\mathrm{S}}$ are nearer the margin than the larger Byrd $_{1}$ and Byrd $_{2}$ features, and therefore have even steeper ice-surface gradients. RES reveals each to be located in an area of rough basal topography and of regional surface crevassing (Fig 3a, c and d). Byrd ${ }_{\mathrm{S} 1}$ (Fig. 3c) and Byrd S2 (Fig. 3a) show no distinguishing bed features to differentiate them from their surroundings (e.g. flatness, smoothness, relative brightness and/or presence of a hydraulic potential well). Although part of Byrd S3 $_{3}$ is associated with a bright but convex RES reflector, its shape indicates that it is unlikely to form a hydrological sink (Fig. 3d).

Byrd $_{\text {S5 }}$ is upstream of Byrd 2 and is very likely to be hydraulically linked along a single flow path with several other small ice-surface height change features identified by ICESat, but which were not crossed by the flight tracks of the ICECAP survey (Fig. 2). These features are located in the eastern margin of the WSB and in an area where the regional subglacial hydrological potential would act to drive water southwards, parallel to the basin margin and the transition from deep basin sediments to mountainous coastal terrain. While RES indicates that Byrd ${ }_{\mathrm{S} 5}$ is near an area of bright, smooth basal reflections (Fig. 3e), and therefore possibly a wet bed, the reflections beneath the feature itself are indistinct from its surroundings (Fig. 3e).

Byrd $_{\mathrm{S9}}$ and Byrd $\mathrm{S} 15_{5}$ are both situated beneath $3000 \mathrm{~m}$ thick ice and are far away from any surface crevassing. In neither case does RES exhibit either a smoother basal interface or a higher reflectivity than their surroundings (Figs $3 f$ and 4).

At none of the ICESat 'active' lake sites described above do our RES investigations reveal evidence of a smooth, uniformly bright and hydraulically flat reflection normally diagnostic of a substantial body of subglacial water. We cannot, however, rule out the presence of small amounts of water (e.g. in a linked-cavity system), as these may not be fully detectable with our geophysical methods. The relationship between the extent of the ICESat ice-surface change and the size of the basal disturbance needed to create it is still uncertain (Smith and others, 2009). Hence, if very small subglacial lakes (less than $\sim 400 \mathrm{~m}$ in length) are responsible for producing these observations, then they may also not be detectable by our current RES methods.

Only at Byrd ${ }_{\mathrm{S} 11}$ and Byrd $\mathrm{S} 12_{2}$ are RES characteristics at the ice-sheet bed readily distinguishable from their surroundings. In both cases, RES reflections show some, but not all, of the characteristics often associated with subglacial lakes. Byrd $_{\text {s11 }}$ appears to occupy a broad, shallow, smooth-floored basin into which internal layers dip sharply. Bed reflection strength here also appears to increase in the direction of ice flow, in line with RES-based predictions for subglacial lakes (Fig. 3g). Apart from its gently undulating topography, which also exhibits reflection parabolas within the boundaries of the potential lake, Byrds12 exhibits a bright reflector and appears to be a drawdown site for englacial layers, possibly indicating that it has been a site of basal melting (Fig. 3h). This is the same site that Smith and others (2009) observed to be filling during the ICESat period of operation but was 

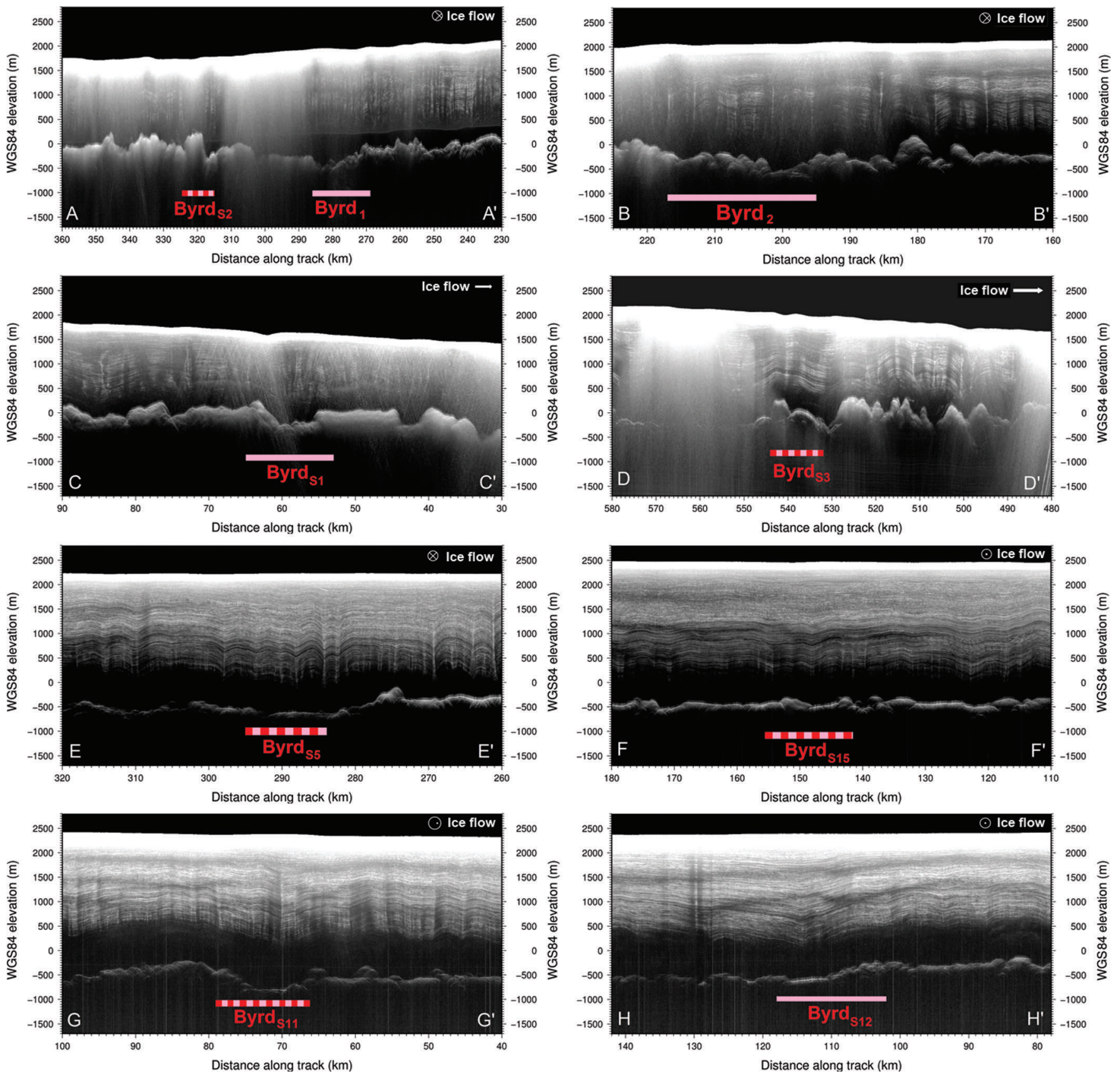

Fig. 3. Radargrams from the ICECAP survey of the southern part of the Wilkes Subglacial Basin. The corresponding locations are shown in Figure $2 \mathrm{~b}$. In each case, one or more of the proposed subglacial lakes identified from ICESat observations of rapid, localized surface height change are crossed by the radar transect. Surface height change features are located on the radar transects by bars which indicate whether the site was predominantly rising (solid) or falling (dashed). The approximate ice-flow direction is shown in the upper right corner of each radargram; circular symbols indicate where this is predominantly into (crossed) or out of (dotted) the page.

then found by Welch and others (2009) to be drained in 2007/08, suggesting a complicated history and/or a rapid response time. Neither at Byrd ${ }_{\mathrm{S} 11}$ nor Byrd S12 $_{12}$ do RES data reveal a sufficiently clear bed reflection to allow a subglacial lake to be positively identified. That said, our RES observations cannot rule out the presence of basal water at either of these sites.

In summary, through analysis of the ICECAP RES data, we find no evidence of a subglacial lake at nine of the eleven ICESat 'active' lake sites investigated (Byrd 1, Byrd $_{2}$, Byrd $_{\mathrm{S1}}$,

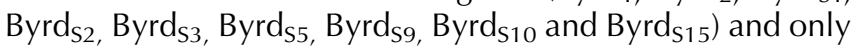
equivocal evidence for lakes at the remaining two sites (Byrd $_{\mathrm{S} 11}$ and Byrd $\mathrm{s} 12_{2}$ ). Following the classification scheme of Carter and others (2007) these would be categorized as a very dim lake $\left(\right.$ Byrd $\left._{\mathrm{s} 11}\right)$ and as a fuzzy lake (Byrd $\left.\mathrm{S}_{\mathrm{S} 2}\right)$. Previous studies (Welch and others, 2009; Langley and others, 2011; Wright and others, 2012) that have used RES to investigate ICESat ice-surface height changes have reported similar observations, interpreted as evidence of 'drained' lakes. In this study a sufficiently large number of ICESat icesurface height change features have been investigated to allow us to effectively rule out the possibility that they will all be drained simultaneously. While the RES data indicate strongly that large deep-water lakes do not exist at the majority of the ice-surface height change sites, they cannot reliably be used to either infer or discount the presence of smaller quantities of basal water, either at these locations or elsewhere. We conclude that the ICESat ice-surface height 


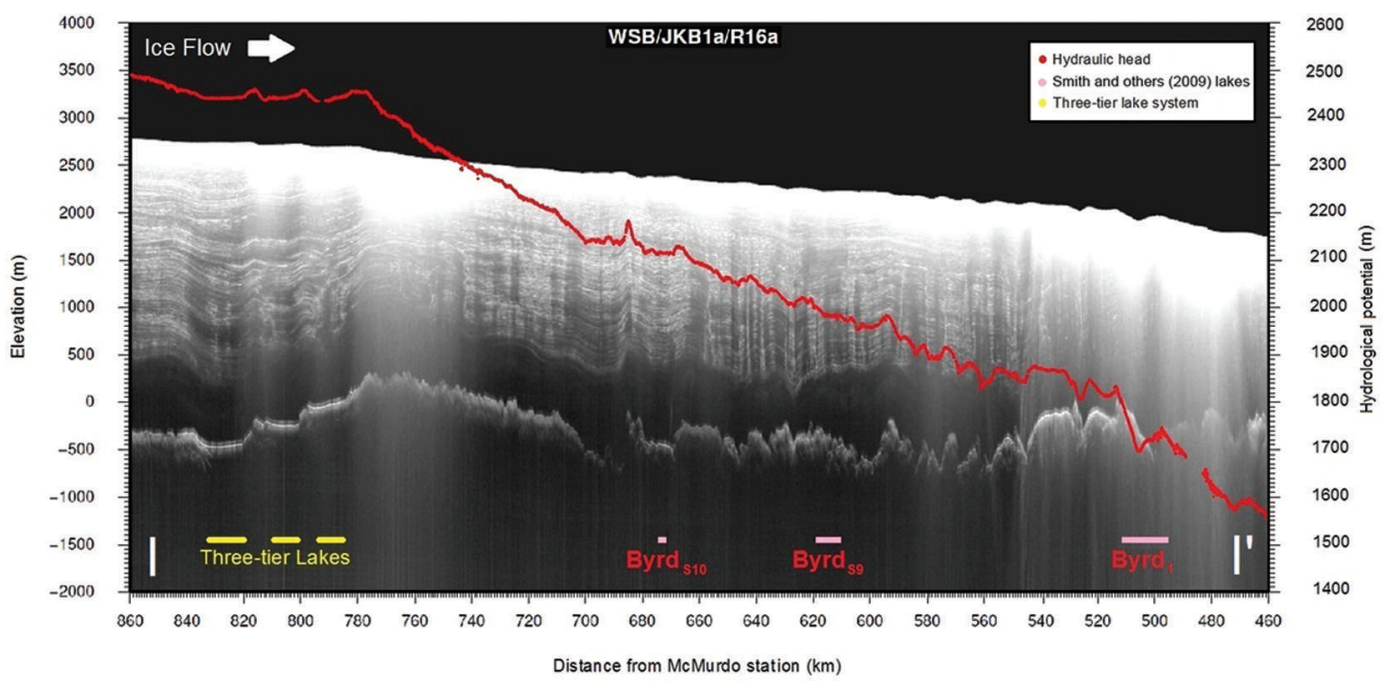

Fig. 4. A single radargram from the ICECAP survey crossing the three-tier lake system and also the Byrd ${ }_{1}$, Byrd $\mathrm{S}_{\mathrm{S9}}$ and Byrd $\mathrm{S}_{\mathrm{S} 10}$ ice-surface height change features identified by Smith and others (2009). The location of this transect is shown in Figure $2 \mathrm{~b}$. The three-tier lake formation results from the stepwise movement of water up the stoss face of a broad ridge in the bed topography. Ice flow is from left to right in the image, which has been corrected for aircraft altitude changes. The hydraulic potential head is shown in red against the right-hand axis. This shows that the potential gradient is near zero across the lakes region, but that potential barriers exist along this line between the individual lakes.

changes within the Byrd subglacial catchment are not the result of subglacial lakes filling and draining, but may be caused by small quantities of subglacial water moving along drainage pathways beneath the ice sheet.

\subsection{Water storage in the upper Byrd catchment}

During the ICECAP survey, significant water storage was identified in the vicinity of a bedrock ridge running approximately along the $130^{\circ} \mathrm{E}$ meridian. At $82.2^{\circ} \mathrm{S}$ three subglacial lakes were found that demonstrate clearly the progression of water driven against the stoss face of this ridge by the changing pressure associated with decreasing ice thickness (named here as the three-tier lake system; Figs $2 \mathrm{~b}$ and 4 ). Located $\sim 500 \mathrm{~km}$ inland from the grounding line of Byrd Glacier, these three subglacial lakes are in an area of intermediate regional ice surface slope $\left(\sim 0.12^{\circ}\right)$ and, therefore, of relatively steep hydraulic gradient compared with subglacial lakes near the ice divide. At the bedrock ridge (shown in cross section in Fig. 4), the basal topography rises by $900 \mathrm{~m}$ over a distance of $70 \mathrm{~km}$. The regional bed gradient is therefore about six times steeper and in the opposite direction to the surface slope. The RES data indicate subglacial water has ponded at three separate levels on the stoss face of this bedrock obstacle. Each of the three lakes is between 11 and $15 \mathrm{~km}$ in length along the RES flight track and they are separated by bedrock steps between 200 and $300 \mathrm{~m}$ high, which each correspond to areas of surface crevassing (Fig. 5). The lakes themselves relate to flat, featureless areas on the ice surface devoid of the 'megadunes' that are prevalent throughout the region, and are clearly visible in Moderate Resolution Imaging Spectroradiometer (MODIS) Mosaic of Antarctica (MOA) imagery (Fig. 5 inset). A substantial amount of surface crevassing is present over the summit of the bedrock ridge (Fig. 4), but the bed remains bright and clearly visible throughout.

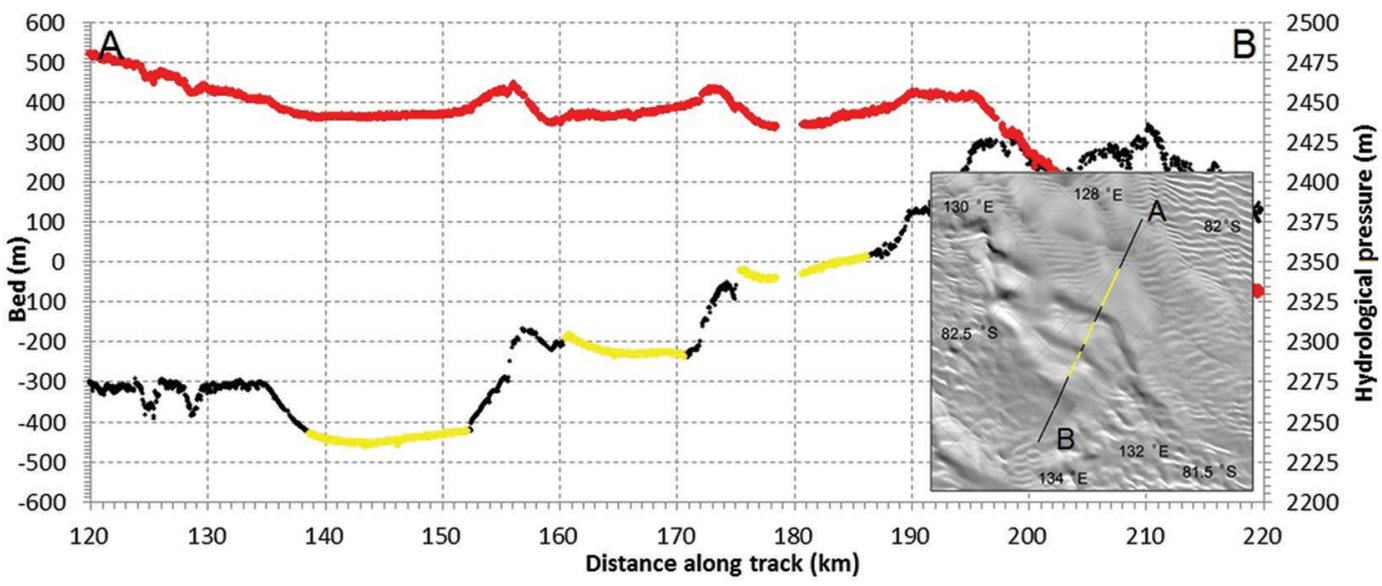

Fig. 5. Profile of bed elevation (black) and subglacial hydrological potential (red) across the three-tier lake system with RES-derived lake locations indicated in yellow. Ice flow is from left to right in the image. Inset is the MODIS MOA (Haran and others, 2006) showing the three-tier lakes area. Flat features separated by down-steps of $\sim 20 \mathrm{~m}$ in the ice-sheet surface topography can be seen to correspond with the lake locations. 


\subsection{Hydraulic connectivity in the Byrd catchment}

The radargram in Figure 4 closely follows the predicted flow path for subglacial water draining from the three-tier lake system (Fig. 2). Downstream of the bedrock ridge, relatively bright basal reflections occur where the flight track crosses the margin of Byrd $\mathrm{S}_{\mathrm{S} 0}$, upstream of Byrd $\mathrm{s}_{\mathrm{S}}$, and again, more strongly, just upstream of Byrd ${ }_{1}$. These bright RES returns suggest that subglacial water is present at intervals along this flow path and allow us to formulate the hypothesis that hydrological connectivity may exist, perhaps intermittently, between a persistent store of basal water at the three-tier lake system and a series of downstream shallow hydropotential wells which fill and drain over short time periods. If this is the case, the dynamics of the Byrd Glacier trunk may be affected by hydrological processes that occur hundreds of kilometres upstream, although the nature of such processes remains insufficiently understood.

\section{CONCLUSIONS}

RES data from the ICECAP survey of the southern WSB confirm that the majority of persistent large-scale basal water storage occurs near the ice divide, with the greatest concentration in the vicinity of Dome C, where many subice lakes are known to exist. The survey acquired RES data from 11 sites interpreted previously from ICESat measurements to be locations of 'active' subglacial lakes. RES amplitude data suggest the presence of subglacial water in only two of these cases, and neither of these is comparable to the bright, flat, smooth reflectors from known deep-water subglacial lakes (e.g. Vostok Subglacial Lake). In the remainder of cases, RES reveals markedly undulating bed reflectors with varying degrees of brightness, which are indistinguishable from the surrounding bed.

We conclude that the ice-sheet surface slope within the lower part of the Byrd Glacier catchment is too great for subglacial water to pond either to any great depth or over a large area. As water depths less than $10 \mathrm{~m}$ across a region of $<1 \mathrm{~km}^{2}$ may not have the appearance of 'classical' subglacial lakes in RES records (e.g. Gorman and Siegert, 1999), we cannot rule out their occurrence within the Byrd basin. Indeed, we anticipate that such 'shallow ponds' may be commonplace here. These features are likely to be highly transitory, draining and filling over short timescales and leaving little or no trace of their presence detectable by current ice-penetrating RES methods.

Three new subglacial lakes, collectively named the threetier lake system, have been identified at ascending elevations across the stoss face of a large subglacial ridge $\sim 500 \mathrm{~km}$ upstream of Byrd Glacier. Basal water flow paths, based on available bed and ice-surface data, indicate that water from the three-tier lake system will flow into the Byrd Glacier trunk, via several proposed 'active' lakes. Further RES survey, particularly of the still poorly sampled upstream area around the three-tier lake system, may increase our understanding of how this water transfer may occur, and whether there is a link between lake discharges from the ice-sheet interior and changes to enhanced ice flow downstream.

\section{ACKNOWLEDGEMENTS}

This work was supported by UK Natural Environment Research Council grants NE/D003733/1, NE/G00465X/1 and NE/G013071/1, US National Science Foundation grant
ANT-0733025 and NASA grants NNX08AN68G and NNX09AR52G (Operation IceBridge), the Jackson School of Geosciences and the G. Unger Vetlesen Foundation. This is University of Texas Institute for Geophysics (UTIG) contribution No. 2589.

\section{REFERENCES}

Bamber JL, Gomez-Dans JL and Griggs JA (2009) A new 1 km digital elevation model of the Antarctic derived from combined satellite radar and laser data - Part 1: data and methods. Cryosphere, 3(1), 101-111 (doi: 10.5194/tc-3-101-2009)

Bell RE, Studinger M, Shuman CA, Fahnestock MA and Joughin I (2007) Large subglacial lakes in East Antarctica at the onset of fast-flowing ice streams. Nature, 445(7130), 904-907 (doi: 10.1038/nature05554)

Carter SP, Blankenship DD, Peters MF, Young DA, Holt JW and Morse DL (2007) Radar-based subglacial lake classification in Antarctica. Geochem. Geophys. Geosyst., 8(3), Q03016 (doi: 10.1029/2006GC001408)

Christianson K, Jacobel RW, Horgan HJ, Anandakrishnan S and Alley RB (2012) Subglacial Lake Whillans - ice-penetrating radar and GPS observations of a shallow active reservoir beneath a West Antarctic ice stream. Earth Planet. Sci. Lett., 331-332, 237-245 (doi: 10.1016/j.epsl.2012.03.013)

Dowdeswell JA and Evans S (2004) Investigations of the form and flow of ice sheets and glaciers using radio-echo sounding. Rep. Progr. Phys., 67(10), 1821-1861 (doi: 10.1088/0034-4885/67/ 10/R03)

Gorman MR and Siegert MJ (1999) Penetration of Antarctic subglacial lakes by VHF electromagnetic pulses: information on the depth and electrical conductivity of basal water bodies. J. Geophys. Res., 104(B12), 29311-29320 (doi: 10.1029/ 1999JB900271)

Griggs JA and Bamber JL (2009) A new 1 km digital elevation model of Antarctica derived from combined radar and laser data - Part 2: validation and error estimates. Cryosphere, 3(1), 113-123 (doi: 10.5194/tc-3-113-2009)

Haran T, Bohlander J, Scambos T, Painter T and Fahnestock M (2006) MODIS mosaic of Antarctica (MOA) image map. National Snow and Ice Data Center, Boulder, CO. Digital media: http://nsidc.org/data/moa

Horgan HJ and 7 others (2012) Subglacial Lake Whillans - seismic observations of a shallow active reservoir beneath a West Antarctic ice stream. Earth Planet. Sci. Lett., 331-332, 201-209 (doi: 10.1016/j.epsl.2012.02.023)

Langley $\mathrm{K}$ and 8 others (2011) Recovery Lakes, East Antarctica: radar assessment of sub-glacial water extent. Geophys. Res. Lett., 38(5), L05501 (doi: 10.1029/2010GL046094)

Lythe MB, Vaughan DG and BEDMAP consortium (2001) BEDMAP: a new ice thickness and subglacial topographic model of Antarctica. J. Geophys. Res., 106(B6), 11335-11351 (doi: 10.1029/2000JB900449)

Matsuoka K (2011) Pitfalls in radar diagnosis of ice-sheet bed conditions: lessons from englacial attenuation models. Geophys. Res. Lett., 38(5), L05505 (doi: 10.1029/2010GL046205)

Oswald GKA and Robin GdeQ (1973) Lakes beneath the Antarctic ice sheet. Nature, 245(5423), 251-254 (doi: 10.1038/245251a0)

Peters ME, Blankenship DD and Morse DL (2005) Analysis techniques for coherent airborne radar sounding: application to West Antarctic ice streams. J. Geophys. Res., 110(B6), B06303 (doi: 10.1029/2004JB003222)

Robin GdeQ, Swithinbank CWM and Smith BME (1970) Radio echo exploration of the Antarctic ice sheet. IASH Publ. 86 (Symposium at Hanover 1968 - Antarctic Glaciological Exploration (ISAGE)), 97-115

Shreve RL (1972) Movement of water in glaciers. J. Glaciol., 11(62), 205-214

Sibson R (1981) A brief description of natural neighbor interpolation. In Barnett $\mathrm{V}$ ed. Interpreting multivariate data. Wiley, New York, 21-36 
Siegert MJ and Bamber JL (2000) Correspondence. Subglacial water at the heads of Antarctic ice-stream tributaries. J. Glaciol., 46(155), 702-703 (doi: 10.3189/172756500781832783)

Siegert MJ, Carter S, Tabacco I, Popov S and Blankenship DD (2005) A revised inventory of Antarctic subglacial lakes. Antarct. Sci., 17(3), 453-460 (doi: 10.1017/S0954102005002889)

Siegert MJ and 8 others (2014) Boundary conditions of an active West Antarctic subglacial lake: implications for storage of water beneath the ice sheet. Cryosphere, 8, 15-24 (doi:10.5194/tc-815-2014)

Smith BE, Fricker HA, Joughin IR and Tulaczyk S (2009) An inventory of active subglacial lakes in Antarctica detected by ICESat (2003-2008). J. Glaciol., 55(192), 573-595 (doi: 10.3189/002214309789470879)

Stearns LA, Smith BE and Hamilton GS (2008) Increased flow speed on a large East Antarctic outlet glacier caused by subglacial floods. Nature Geosci., 1(12), 827-831 (doi: 10.1038/ngeo356)

Studinger M and 11 others (2003) Ice cover, landscape setting, and geological framework of Lake Vostok, East Antarctica. Earth Planet. Sci. Lett., 205(3-4), 195-210 (doi: 10.1016/S0012821X(02)01041-5)
Studinger M, Bell RE, Buck WR, Karner GD and Blankenship DD (2004) Sub-ice geology inland of the Transantarctic Mountains in light of aerogeophysical data. Earth Planet. Sci. Lett., 220(3-4), 391-408 (doi: 10.1016/S0012-821X(04)00066-4)

Welch BC, Jacobel RW and Arcone SA (2009) First results from radar profiles collected along the US-ITASE traverse from Taylor Dome to South Pole (2006-2008). Ann. Glaciol., 50(51), 35-41 (doi: 10.3189/172756409789097496)

Wright A and Siegert MJ (2011) The identification and physiographical setting of Antarctic subglacial lakes: an update based on recent discoveries. In Siegert MJ, Kennicutt $\mathrm{MCl}$ and Bindschadler RA eds. Antarctic subglacial aquatic environments. (Geophysical Monograph Series 192) American Geophysical Union, Washington, DC, 9-26

Wright AP, Siegert MJ, Le Brocq AM and Gore DB (2008) High sensitivity of subglacial hydrological pathways in Antarctica to small ice-sheet changes. Geophys. Res. Lett., 35(17), L17504 (doi: 10.1029/2008GL034937)

Wright AP and 12 others (2012) Evidence of a hydrological connection between the ice divide and ice sheet margin in the Aurora Subglacial Basin, East Antarctica. J. Geophys. Res., 117(F1), F01033 (doi: 10.1029/2011JF002066)

MS received 21 January 2013 and accepted in revised form 13 December 2013 